\title{
Evaluation of College Students' Innovation and Entrepreneurial Ability for the Science and Technology Service Industry
}

\author{
https://doi.org/10.3991/ijet.v16i05.21079 \\ Yanming Qi \\ Hebei University of Engineering, Handan, China \\ Tong Liang \\ Hebei University, Baoding, China \\ Yongzhi Chang $(\bowtie)$ \\ North China Institute of Aerospace Engineering, Langfang, China \\ changyzeigsnrr.ac.cn
}

\begin{abstract}
The development level of the science and technology service industry is an important factor affecting the development speed of regional economy and the formation of innovation ability and development potential of the region, and the construction of talent team is the core and foundation for the development of the science and technology service industry. To measure such ability, this paper constructed an evaluation model for the innovation and entrepreneurial ability (IEA) of college students. First, a corresponding evaluation index system was established, the quantifiable index data were subject to factor analysis, and the structural equation model was subject to regression estimation using the maximum likelihood method. Then, from multiple aspects such as the level of the colleges, the major of the students, and the gender of the students, this paper comprehensively analyzed college students' IEA. And finally, based on one-way analysis of variance, the differences between indexes were analyzed, and a path analysis model was established to analyze the relationship between the science and technology service industry's regional industrial scale, resource input, informatization level, spatial agglomeration degree, and college students' IEA.
\end{abstract}

Keywords - Science and technology service industry, innovation and entrepreneurial ability (IEA) of college students, ability evaluation

\section{Introduction}

In China, the state council promulgated the Several Opinions of the State Council on Accelerating the Development of the Science and Technology Service Industry in 2014 and the Modern Service Industry Science and Technology Innovation Special Plan for "13th Five-Year Plan" in 2017, and the two documents had specified the important role of the knowledge spillover effect of the science and technology service 
industry in promoting the development of the national modern industrial system and the optimization of the industrial structure [1-3].

As an emerging industry, the development level of the science and technology service industry determines the development speed of regional economy and the formation of the innovation ability and development potential of the region; now, the science and technology service industry has received national attention and various supports such as resources, taxes, subsidies from the local governments [4-8]. In 2010, the Ministry of Education issued the Measures for the Certification of College Students' Science and Technology Entrepreneurship Practice Bases and the Opinions on Vigorously Promoting the Innovation and Entrepreneurship Education of Colleges and Universities and the Independent Entrepreneurship of College Students, and these two documents had pointed out the direction for the development of college students' innovation and entrepreneurship education [9-10]. Effectively cultivating college students' IEA is not only an objective requirement for promoting the innovation ability of the science and technology service industry, but also a task assigned to colleges and universities during the process of building China into an innovative country.

Scholars at home and abroad have attached great importance to the cultivation and introduction of innovative talents in the science and technology service industry. For example, Sadli et al. [11] believe that the innovative talents of the science and technology service industry should have certain professional knowledge, skills, and good innovation ability; and no matter theory-type talents, application-type talents, or skilltype talents, all of them can become innovative talents via efforts. Yu et al. [12] believed that senior professional titles or honorary titles are not a sufficient and necessary condition for innovative talents in the science and technology service industry. Talents with high professional quality, or certain innovation ability in science, technology or management, or have contributions in promoting scientific and technological achievements in the society, can all be called the innovative talents in the science and technology service industry.

In 1998, UNESCO proposed that the important development goal of higher education in the 21 st century is to cultivate students with both entrepreneurial skills and spirits, and thus realizing the transformation of outstanding university graduates from job seekers to entrepreneurs [13-14].

Nearly 1,600 colleges and universities in the United States have opened small business management and innovation and entrepreneurship courses for students at the undergraduate level, various innovation and entrepreneurship competitions have been held to assist and promote such courses. Other developed countries such as Europe and Japan have also provided various supports for college students' innovation and entrepreneurship via policies, resources, and funding, etc. [15-18].

Efendi et al. [19] constructed a conceptual model of innovation and entrepreneurship education that can distinguish student types and styles, and they argued that the goals and methods of education are jointly determined by students' entrepreneurial needs, awareness, and potential. Perez-Encinas et al. [20] investigated the innovation and entrepreneurship education activities of 6 universities in Germany, and pointed out that entrepreneurship practice is the best way for students to apply the theoretical knowledge they learnt in class.

In China, with "achieving dreams via Internet + and creating future via innovation and entrepreneurship" as the theme, each year, the country will hold the Internet+ 
College Student Innovation and Entrepreneurship Competition; and every two years, the country will hold the "Challenge Cup" National College Students' Extracurricular Academic Science and Technology Competition. Under the national call of mass entrepreneurship and innovation, these events aim to cultivate the new force for scientific and technological innovation, and promote the transformation of competition results, and the formation of the new "Internet + " science and technology service industry [21-24]. Gumbi and Van Der Westhuizen [25] explained such competitions and proposed the idea of innovation and entrepreneurship education of "1-center, 3platforms, 9-training modules", and constructed a long-term operation mechanism integrated four aspect of theory, research, exercise, and practice.

After reviewing relevant literatures, we found that, in terms of the cultivation and introduction of innovative talents for the science and technology service industry and the training of college students' IEA, different countries and regions have different evaluation standards for students and talents due to the differences in their cultivation modes and education concepts, and their evaluation tools are varied as well. In this context, the construction of a scientific evaluation system for college students' IEA has become a practical need.

In respond to this need, and in order to obtain accurate evaluation results of college students' IEA for the science and industry service industry, this paper proposed a novel evaluation model for the said ability, in the hopes of satisfying the requirements of technological innovation, enterprise innovation, regional innovation and national innovation.

The structure of the content in this paper is arranged as follows: the second part built the corresponding evaluation index system for the said model, and conducted SPSS factor analysis and AMOS confirmatory factor analysis on the quantifiable index data, and then performed regression estimation on the corresponding structural equation model based on the maximum likelihood method. The third part comprehensively analyzed college students' IEA from multiple aspects such as the level of the college, the major of the student, and the gender of the student. The fourth part took the level of the college, the major of the student, and the gender of the student as the independent variables, and college students' IEA as dependent variable to conduct the one-way analysis of variance. At last, a path analysis model was established to analyze the relationship between the science and technology service industry's regional industrial scale, resource input, informatization level, spatial agglomeration degree, and college students' IEA.

\section{Evaluation of College Students' IEA for the Science and Technology Service Industry}

The structural equation model (SEM) can handle multiple sets of latent variables that cannot be directly observed in the fields of sociology and psychology, and clearly describe the direct or indirect influence relationship between variables. Using this method, the measurement error of the variables would have little effect on the results, which is obviously better than the traditional statistical method. Figure 1 gives the basic analysis process of the constructed SEM. According to the figure, when using this model to analyze the evaluation indexes of college students' IEA for the science 
and technology service industry, there're mainly 5 steps: set index relationship, acquire and identify indexes, linear regression estimation of the model, obtain evaluation results, model adjustment and optimization.

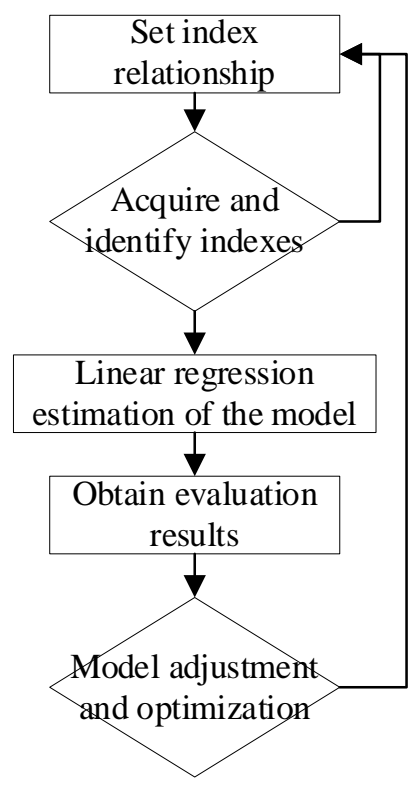

Fig. 1. Analysis flow of SEM

Table 1. IEA evaluation index system

\begin{tabular}{|c|c|c|}
\hline First-level index & Second-level index & Meaning \\
\hline \multirow{3}{*}{ Basic factors } & Talent quality basics & \multirow{3}{*}{$\begin{array}{l}\text { Basic factors of innovative talents for } \\
\text { science and technology service industry }\end{array}$} \\
\hline & Talent growth carrier basics & \\
\hline & Talent growth potential basics & \\
\hline \multirow{3}{*}{$\begin{array}{l}\text { Environmental } \\
\text { factors }\end{array}$} & Regional living environment & \multirow{3}{*}{$\begin{array}{l}\text { Influence of external environment on } \\
\text { college students' IEA for science and } \\
\text { technology service industry }\end{array}$} \\
\hline & Regional economic environment & \\
\hline & Work environment & \\
\hline \multirow{3}{*}{ Input factors } & Talent cultivation investment & \multirow{3}{*}{$\begin{array}{l}\text { The support and input of government and } \\
\text { enterprises in the cultivation of innova- } \\
\text { tive talents for the science and technolo- } \\
\text { gy service industry }\end{array}$} \\
\hline & Scientific research input & \\
\hline & $\begin{array}{l}\text { Talent introduction } \\
\text { Policy input }\end{array}$ & \\
\hline \multirow{5}{*}{ Personal factors } & Innovation and entrepreneurship awareness & \multirow{5}{*}{$\begin{array}{l}\text { Qualities that the innovative talents } \\
\text { should have for the science and technol- } \\
\text { ogy service industry }\end{array}$} \\
\hline & Innovation and entrepreneurship thinking & \\
\hline & Innovation and entrepreneurship spirit & \\
\hline & Innovation and entrepreneurship knowledge & \\
\hline & Innovation and entrepreneurship ability & \\
\hline \multirow{2}{*}{$\begin{array}{l}\text { Achievement } \\
\text { factors }\end{array}$} & $\begin{array}{l}\text { Scientific and technological innovation } \\
\text { achievements }\end{array}$ & \multirow{2}{*}{$\begin{array}{l}\text { New contributions of innovative talents } \\
\text { for the science and technology service } \\
\text { industry }\end{array}$} \\
\hline & Achievement transformation & \\
\hline
\end{tabular}


Based on collected data concerning the evaluation indexes of college students' IEA and the actual situation of innovation and entrepreneurship education in colleges and universities and the development situation of regional science and technology service industry, this paper proposed an evaluation index system of college students' IEA for the science and technology service industry. Wherein the first-level indexes include 5 dimensions, namely: basic factors, environmental factors, input factors, personal factors, and achievement factors, as shown in Table 1. Figure 2 gives a diagram of the constructed model.

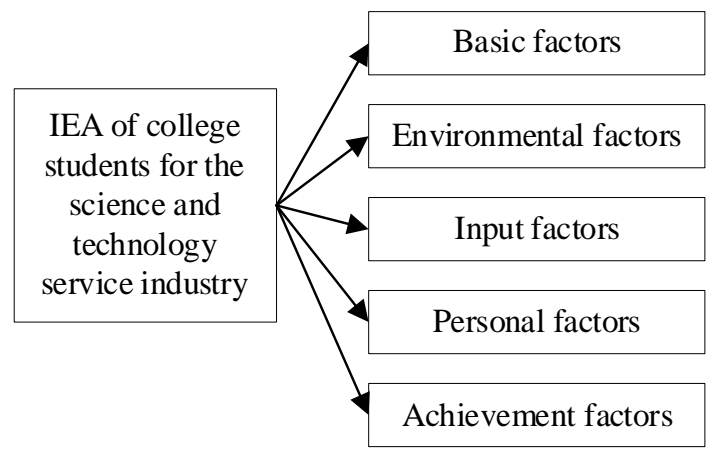

Fig. 2. Structure of IEA evaluation model

Table 2 gives the quantifiable variables of the second-level indexes and theirs codes corresponding to the 5 first-level indexes that are not directly observable in the model shown in Figure 2.

The construction of the above model is based on the following assumptions: indexes of the five dimensions (basic factors, environmental factors, input factors, own factors, and achievement factors) are important factors that affect the IEA of college students for the science and technology service industry, that is, the greater the positive impact of these indexes, the better the IEA of college students.

Above index data were subject to SPSS factor analysis and AMOS confirmatory factor analysis, and the model was subject to regression estimation based on the maximum likelihood method. Figure 3 shows the model after adjustment and optimization. 
Paper-Evaluation of College Students' Innovation and Entrepreneurial Ability for the Science...

Table 2. Evaluation details and codes of the IEA evaluation model

\begin{tabular}{|c|c|c|}
\hline First-level index & Second-level index (quantifiable) & Code \\
\hline \multirow{3}{*}{ Basic factors } & $\begin{array}{l}\text { Innovative talent stock for the science and technology service industry in current } \\
\text { year; Number of college graduates in current year; Proportion of academicians }\end{array}$ & $B E_{1}$ \\
\hline & $\begin{array}{l}\text { Net inflow population in the region; Number of colleges and universities in the } \\
\text { region }\end{array}$ & $B E_{2}$ \\
\hline & $\begin{array}{l}\text { Change rate of innovative talents in science and technology service industry; } \\
\text { Number of college students on campus }\end{array}$ & $B E_{3}$ \\
\hline \multirow{3}{*}{$\begin{array}{l}\text { Environmental } \\
\text { factors }\end{array}$} & Maturity of infrastructure in the region & $E E_{1}$ \\
\hline & $\begin{array}{l}\text { Per capita consumption level in the region; Per capita disposable income in the } \\
\text { region }\end{array}$ & $E E_{2}$ \\
\hline & $\begin{array}{l}\text { Amount of scientific research funding for innovative talents in the science and } \\
\text { technology service industry; Reward for the introduction of innovative talents in } \\
\text { the science and technology service industry }\end{array}$ & $E E_{3}$ \\
\hline \multirow{3}{*}{ Input factors } & $\begin{array}{l}\text { Investment in higher education; Investment in professional skills training; } \\
\text { Introduction and investment in high-end technologies }\end{array}$ & $I E_{1}$ \\
\hline & $\begin{array}{l}\text { Scientific research expenditure; Number of sponsored scientific research pro- } \\
\text { jects }\end{array}$ & $I E_{2}$ \\
\hline & $\begin{array}{l}\text { Proportion of innovative talents introduced in the science and technology service } \\
\text { industry }\end{array}$ & $I E_{3}$ \\
\hline \multirow{5}{*}{ Personal factors } & Needs; motivation; interests; beliefs; values & $O E_{1}$ \\
\hline & Divergent thinking; creative thinking; inspirational thinking & $O E_{2}$ \\
\hline & Enterprising; self-confidence; pioneering spirit; adventurous spirit & $O E_{3}$ \\
\hline & $\begin{array}{l}\text { Professional knowledge; innovation and entrepreneurship theory; interdiscipli- } \\
\text { nary knowledge and common sense }\end{array}$ & $O E_{4}$ \\
\hline & $\begin{array}{l}\text { Social skills; comprehension; adaptability; observation; judgment; imagination; } \\
\text { stress tolerance; learning ability; teamwork ability; self-control; willpower }\end{array}$ & $O E_{5}$ \\
\hline \multirow[b]{2}{*}{$\begin{array}{l}\text { Achievement } \\
\text { factors }\end{array}$} & $\begin{array}{l}\text { Number of patent applications and authorizations; Number of academic papers } \\
\text { published }\end{array}$ & $R E_{1}$ \\
\hline & $\begin{array}{l}\text { Number of technology transformation contracts signed; Per capita horizontal } \\
\text { funding received for innovative talents in the science and technology service } \\
\text { industry; Incremental output value of new products of enterprises after technol- } \\
\text { ogy transformation }\end{array}$ & $R E_{2}$ \\
\hline
\end{tabular}




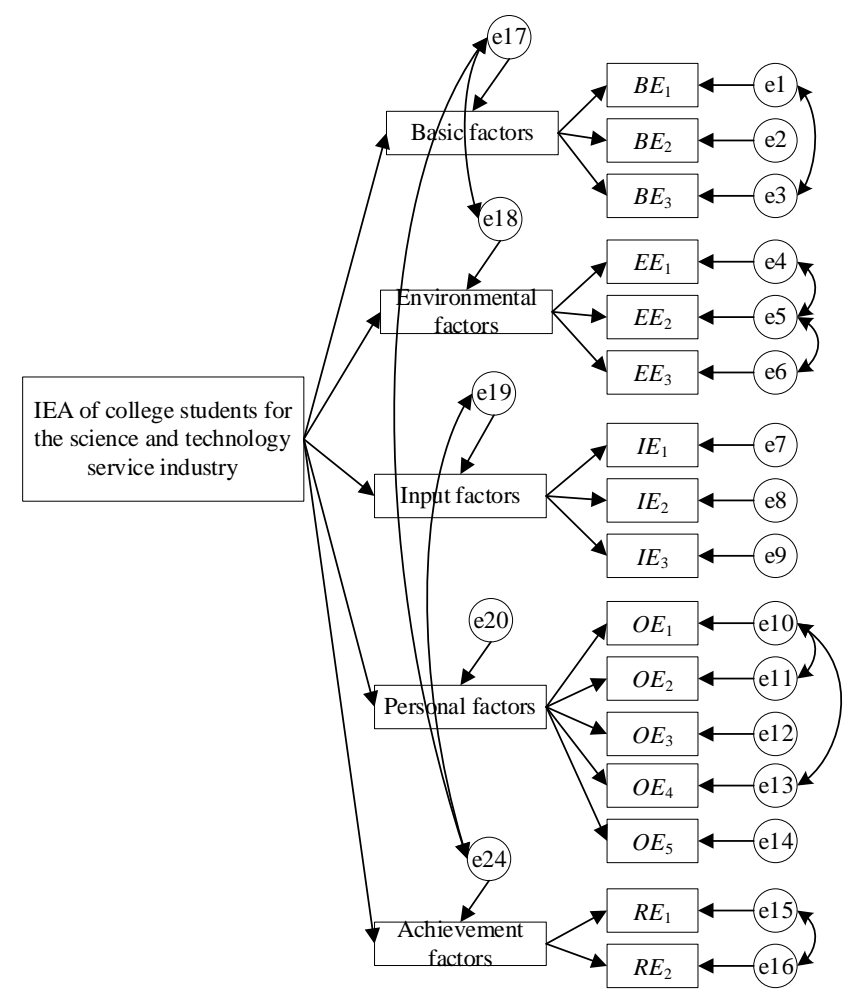

Fig. 3. Structure of the model after adjustment and optimization

Table 3 gives the second-order confirmatory factor analysis and the model fit before and after adjustment and optimization, it can be seen from the table that the fitness values are in an ideal range.

Table 3. Comparison of indexes before and after adjustment and optimization

\begin{tabular}{|l|l|c|c|}
\hline \multicolumn{2}{|c|}{ Calibration index } & $\begin{array}{c}\text { Critical value of } \\
\text { fitness }\end{array}$ & $\begin{array}{c}\text { After adjustment } \\
\text { and optimization }\end{array}$ \\
\hline \multirow{3}{*}{$\begin{array}{l}\text { Absolute fit } \\
\text { index }\end{array}$} & $\mathrm{x}^{2} / \mathrm{df}$ & $<5$ & 3.014 \\
\cline { 2 - 4 } & Root Mean Square Residual (RMSR) & $<0.08$ & 0.031 \\
\cline { 2 - 4 } & Goodness of fix index (GFI) & $>0.9$ & 0.982 \\
\hline \multirow{4}{*}{$\begin{array}{l}\text { Comparative fit } \\
\text { index }\end{array}$} & Normed fit index (NFI) & $>0.9$ & 0.921 \\
\cline { 2 - 4 } & Incremental fit index (IFI) & $>0.9$ & 0.977 \\
\cline { 2 - 4 } & Tucker-Lewis index (TLI) & $>0.9$ & 0.954 \\
\cline { 2 - 4 } & Comparative fit index (CFI) & $>0.9$ & 0.925 \\
\hline \multirow{2}{*}{$\begin{array}{l}\text { Parsimony fit } \\
\text { index }\end{array}$} & Parsimony goodness of fit index (PGFI) & $>0.9$ & 0.916 \\
\cline { 2 - 4 } & Parsimony goodness of fit index (PGFI) & $>0.9$ & 0.970 \\
\hline
\end{tabular}

This paper adopted Crobach's alpha to test the reliability and validity of the model. Table 4 shows the test results. 
Paper-Evaluation of College Students' Innovation and Entrepreneurial Ability for the Science...

Table 4. Test results of the reliability and validity of the model

\begin{tabular}{|c|c|c|c|}
\hline First-level index & Code of second-level index & Load of normalization factor & $\begin{array}{c}\text { Calibration } \\
\text { coefficient }\end{array}$ \\
\hline \multirow{3}{*}{ Basic factors } & $B E_{1}$ & 0.874 & \multirow{3}{*}{0.915} \\
\hline & $B E_{2}$ & 0.827 & \\
\hline & $B E_{3}$ & 0.923 & \\
\hline \multirow{3}{*}{$\begin{array}{l}\text { Environmental } \\
\text { factors }\end{array}$} & $E E_{1}$ & 0.979 & \multirow{3}{*}{0.948} \\
\hline & $E E_{2}$ & 0.862 & \\
\hline & $E E_{3}$ & 0.927 & \\
\hline \multirow{3}{*}{ Input factors } & $I E_{1}$ & 0.913 & \multirow{3}{*}{0.926} \\
\hline & $I E_{2}$ & 0.930 & \\
\hline & $I E_{3}$ & 0.919 & \\
\hline \multirow{5}{*}{ Personal factors } & $O E_{1}$ & 0.879 & \multirow{5}{*}{0.939} \\
\hline & $O E_{2}$ & 0.911 & \\
\hline & $O E_{3}$ & 0.918 & \\
\hline & $O E_{4}$ & 0.942 & \\
\hline & $O E_{5}$ & 0.904 & \\
\hline \multirow{2}{*}{$\begin{array}{l}\text { Achievement } \\
\text { factors }\end{array}$} & $R E_{1}$ & 0.845 & \multirow{2}{*}{0.873} \\
\hline & $R E_{2}$ & 0.886 & \\
\hline
\end{tabular}

According to the table, the values of Crobach's Alpha of the five first-level indexes are all around 0.9 , and values of the load of the normalization factor are between 0.827 and 0.979 , indicating that the model has good reliability and validity. The weight values of the indexes were obtained by dividing the factor load of each firstlevel index by the sum of the factor loads of the five first-level indexes. Table 5 shows the weight values of all first-level indexes.

Table 5. Weight values of indexes

\begin{tabular}{|c|c|c|c|}
\hline First-level index & Weight value & Code of second-level index & Weight value \\
\hline \multirow{3}{*}{ Basic factors } & \multirow{3}{*}{0.159} & $B E_{1}$ & 0.296 \\
\hline & & $B E_{2}$ & 0.325 \\
\hline & & $B E_{3}$ & 0.379 \\
\hline \multirow{3}{*}{ Environmental factors } & \multirow{3}{*}{0.178} & $E E_{1}$ & 0.316 \\
\hline & & $E E_{2}$ & 0.306 \\
\hline & & $E E_{3}$ & 0.378 \\
\hline \multirow{3}{*}{ Input factors } & \multirow{3}{*}{0.226} & $I E_{1}$ & 0.331 \\
\hline & & $I E_{2}$ & 0.337 \\
\hline & & $I E_{3}$ & 0.332 \\
\hline \multirow{5}{*}{ Personal factors } & \multirow{5}{*}{0.231} & $O E_{1}$ & 0.217 \\
\hline & & $O E_{2}$ & 0.195 \\
\hline & & $O E_{3}$ & 0.198 \\
\hline & & $O E_{4}$ & 0.205 \\
\hline & & $O E_{5}$ & 0.185 \\
\hline \multirow{2}{*}{ Achievement factors } & \multirow{2}{*}{0.206} & $R E_{1}$ & 0.521 \\
\hline & & $R E_{2}$ & 0.479 \\
\hline
\end{tabular}


The evaluation formula can be drawn as: College students' IEA $=0.159 \times$ basic factors $+0.178 \times$ environmental factors $+0.226 \times$ input factors $+0.231 \times$ personal factors $+0.206 \times$ achievement factors.

\section{Comprehensive Evaluation of College Students' IEA for the Science and Technology Service Industry}

Based on the evaluation model and evaluation indexes proposed above, college students' IEA was measured, compared and analyzed comprehensively using the 5 first-level indexes from the aspects of the level of college, the major of student, and the gender of students in different regions.

Table 6. Evaluation results for colleges of different levels

\begin{tabular}{|l|c|c|c|c|c|c|}
\hline \multirow{2}{*}{ Level of college } & Score & \multicolumn{5}{|c|}{ Evaluation of each first-level index } \\
\cline { 3 - 7 } & & $\begin{array}{c}\text { Basic } \\
\text { factors }\end{array}$ & $\begin{array}{c}\text { Environmental } \\
\text { factors }\end{array}$ & $\begin{array}{c}\text { Input } \\
\text { factors }\end{array}$ & $\begin{array}{c}\text { Personal } \\
\text { factors }\end{array}$ & $\begin{array}{c}\text { Achievement } \\
\text { factors }\end{array}$ \\
\hline First-tier & 4.416 & 4.316 & 4.325 & 4.452 & 4.428 & 4.561 \\
\hline Second-tier & 4.152 & 4.121 & 4.212 & 4.216 & 4.353 & 3.859 \\
\hline Others & 3.946 & 4.046 & 4.131 & 4.052 & 4.275 & 3.227 \\
\hline Mean & 4.172 & 4.161 & 4.223 & 4.240 & 4.352 & 3.882 \\
\hline
\end{tabular}

Table 6 shows the evaluation results of college students' IEA from the aspect of different-level colleges. According to the table, in terms of the evaluation scores of each first-level index, college students from "double first-class", "985", "211", and "national demonstration higher vocational colleges" and other national-level (firsttier) colleges have the highest-level IEA; followed by college students from provincial colleges and universities (second-tier); and college students from general higher educational schools have the lowest evaluation scores. For students from differentlevel colleges, their scores of personal factors are the highest, and the scores of basic factors are the lowest. In terms of achievement factors, there are great differences in colleges of different levels.

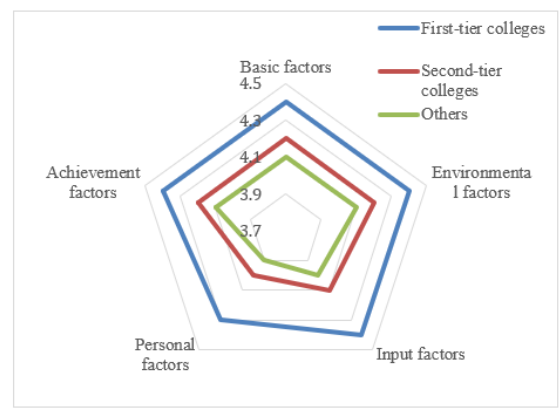

Fig. 4. Evaluation of colleges of different levels (radar chart) 
Figure 4 gives the comparison and analysis results in the form radar chart. According to the figure, on the one hand, for colleges of different levels, the students' IEA levels are different as well. First-tier college students' IEA level is the highest, college students from general higher educational schools have the lowest IEA level; on the other hand, for colleges of a same level, their scores in the five first-level indexes are also different. Through observation, we can know that, for colleges students from second-tier colleges and general higher educational schools, the score in the achievement factors is the lowest and the difference is the largest, respectively 3.859 and 3.227 , and the score of first-tier colleges in achievement factors is 4.561. Except for the scores of achievement factors, the scores of other first-level indexes are all above 4 , and the difference between different indexes is less than 0.2 .

Table 7 shows the evaluation results of college students' IEA from the aspect of different major students. According to the table, in terms of different-type majors, the rank of scores of college students' IEA from high to low is: comprehensive majors, engineering majors, science majors, medicine majors, art majors, management majors, law majors, and liberal art majors. In terms of the mean value of each first-level index, the IEA level of college students majored in liberal arts is the lowest; and they have a great gap with college students of other type majors in terms of the scores of two first-level indexes: the input factors and the achievement factors.

Table 7. Evaluation results for students of different type majors

\begin{tabular}{|l|c|c|c|c|c|c|}
\hline \multirow{2}{*}{\multicolumn{1}{c|}{ Type of major }} & \multirow{2}{*}{ Score } & \multicolumn{5}{c|}{ Evaluation of each first-level index } \\
\cline { 3 - 7 } & & $\begin{array}{c}\text { Basic } \\
\text { factors }\end{array}$ & $\begin{array}{c}\text { Environmental } \\
\text { factors }\end{array}$ & $\begin{array}{c}\text { Input } \\
\text { factors }\end{array}$ & $\begin{array}{c}\text { Personal } \\
\text { factors }\end{array}$ & $\begin{array}{c}\text { Achievement } \\
\text { factors }\end{array}$ \\
\hline Comprehensive majors & 4.399 & 4.327 & 4.353 & 4.466 & 4.432 & 4.421 \\
\hline Engineering majors & 4.254 & 4.311 & 4.278 & 4.274 & 4.126 & 4.281 \\
\hline Science majors & 4.145 & 4.175 & 4.097 & 4.259 & 4.125 & 4.069 \\
\hline Medicine majors & 4.091 & 4.059 & 4.021 & 4.195 & 4.156 & 4.025 \\
\hline Management majors & 3.997 & 4.011 & 4.152 & 4.032 & 3.845 & 3.946 \\
\hline Law majors & 3.920 & 4.033 & 4.021 & 3.941 & 3.847 & 3.759 \\
\hline Liberal art majors & 3.278 & 3.528 & 3.587 & 3.142 & 3.459 & 3.178 \\
\hline Art majors & 3.998 & 3.845 & 3.974 & 4.018 & 4.278 & 3.876 \\
\hline Mean & 4.010 & 3.998 & 4.022 & 4.090 & 3.996 & 3.944 \\
\hline
\end{tabular}

Table 8 shows the evaluation results of college students' IEA from the aspect of different gender students. According to the table, male college students' IEA scores are generally higher than female college students, the overall IEA score of male students is 0.053 higher than that of female students, and the difference in each first-level index is not obvious. 
Table 8. Evaluation results for students of different genders

\begin{tabular}{|l|c|c|c|c|c|c|}
\hline \multirow{2}{*}{ Gender } & \multirow{2}{*}{ Score } & \multicolumn{5}{|c|}{ Evaluation of each first-level index } \\
\cline { 3 - 7 } & & $\begin{array}{c}\text { Basic } \\
\text { factors }\end{array}$ & $\begin{array}{c}\text { Environmental } \\
\text { factors }\end{array}$ & $\begin{array}{c}\text { Input } \\
\text { factors }\end{array}$ & $\begin{array}{c}\text { Personal } \\
\text { factors }\end{array}$ & $\begin{array}{c}\text { Achievement } \\
\text { factors }\end{array}$ \\
\hline Male students & 4.359 & 4.375 & 4.298 & 4.336 & 4.428 & 4.361 \\
\hline Female students & 4.306 & 4.221 & 4.241 & 4.331 & 4.387 & 4.354 \\
\hline Mean & 4.333 & 4.298 & 4.2695 & 4.3335 & 4.4075 & 4.3575 \\
\hline
\end{tabular}

\section{Influencing Factors of College Students' IEA for Science and Technology Service Industry}

Based on one-way analysis of variance, this paper took the level of college, the major of student, and the gender of student as the independent variables, and the college students' IEA as dependent variable to construct a path analysis model, so as to analyze the relationship between the science and technology service industry's regional industrial scale, resource input, informatization level, spatial agglomeration degree, and college students' IEA.

\subsection{Difference analysis}

First, college students' IEA was subject to the difference analysis. Table 9 shows the difference analysis results. According to the table, there are significant differences in the scores of the five first-level indexes of college students from different level colleges, students from general higher education schools have lower mean score in their IEA.

Table 9. Difference in IEA of students from different level colleges

\begin{tabular}{|c|c|c|c|c|}
\hline First-level index & Level of college & Mean & Standard deviation & F value \\
\hline \multirow{3}{*}{ Basic factors } & First-tier & 4.316 & 0.689 & \multirow{3}{*}{$8.691^{* * * *}$} \\
\hline & Second-tier & 4.121 & 0.727 & \\
\hline & Others & 4.046 & 0.628 & \\
\hline \multirow{3}{*}{ Environmental factors } & First-tier & 4.325 & 0.625 & \multirow{3}{*}{$10.274^{* * *}$} \\
\hline & Second-tier & 4.212 & 0.779 & \\
\hline & Others & 4.131 & 0.693 & \\
\hline \multirow{3}{*}{ Input factors } & First-tier & 4.452 & 0.684 & \multirow{3}{*}{$10.943^{* * * *}$} \\
\hline & Second-tier & 4.216 & 0.728 & \\
\hline & Others & 4.052 & 0.684 & \\
\hline \multirow{3}{*}{ Personal factors } & First-tier & 4.428 & 0.774 & \multirow{3}{*}{$14.372^{* * *}$} \\
\hline & Second-tier & 4.353 & 0.827 & \\
\hline & Others & 4.275 & 0.769 & \\
\hline \multirow{3}{*}{ Achievement factors } & First-tier & 4.561 & 0.779 & \multirow{3}{*}{$12.735^{* * *}$} \\
\hline & \begin{tabular}{|l|} 
Second-tier \\
\end{tabular} & 3.859 & 0.749 & \\
\hline & Others & 3.227 & 0.670 & \\
\hline \multirow{3}{*}{ Average level } & First-tier & 4.416 & 0.698 & \multirow{3}{*}{$13.932^{* * *}$} \\
\hline & Second-tier & 4.152 & 0.743 & \\
\hline & Others & 3.946 & 0.638 & \\
\hline
\end{tabular}


Table 10. Post hoc test results of the difference in IEA of college students from different level colleges

\begin{tabular}{|l|l|l|c|c|}
\hline \multicolumn{1}{|c|}{ First-level index } & Level of college & Level of college & Mean difference & Significance difference \\
\hline \multirow{2}{*}{ Basic factors } & \multirow{2}{*}{ First-tier } & Second-tier & 0.195 & 0.002 \\
\cline { 3 - 5 } & & Others & 0.27 & 0.002 \\
\hline \multirow{2}{*}{ Environmental factors } & \multirow{2}{*}{ First-tier } & Second-tier & 0.113 & 0.001 \\
\cline { 3 - 5 } & \multirow{2}{*}{ Input factors } & Others & 0194 & 0.001 \\
\hline \multirow{2}{*}{ Personal factors } & \multirow{2}{*}{ First-tier } & Second-tier & 0.236 & 0.002 \\
\cline { 3 - 5 } & & Others & 0.4 & 0.003 \\
\hline \multirow{2}{*}{ Achievement factors } & \multirow{2}{*}{ First-tier } & Second-tier & 0.075 & 0.000 \\
\cline { 3 - 5 } & & Others & 0.153 & 0.001 \\
\hline \multirow{2}{*}{ Average level } & \multirow{2}{*}{ First-tier } & Oecond-tier & 0.702 & 0.056 \\
\cline { 3 - 5 } & & Others & 1.334 & 0.104 \\
\cline { 3 - 5 } & & Others & 0.264 & 0.002 \\
\hline
\end{tabular}

Table 10 shows the post hoc test results of the difference in the IEA of college students from different level colleges. According to the table, the IEA of students from first-tier colleges in terms of the five first-level indexes is significantly higher than those from second-tier colleges and general higher education schools, this indicates that the IEA of students from second-tier colleges and general higher education schools needs to be strengthened; in terms of input and achievement factors, the assistance and promotion measures need close attention.

Then, the majors were sorted into three major types: science and engineering, liberal arts, and others. Table 11 shows the one-way variance analysis results of the IEA of college students of different major types. According to the table, the IEA of college students majored in science and engineering is better, while the IEA of college students majored in liberal arts needs to be improved. 
Paper-Evaluation of College Students' Innovation and Entrepreneurial Ability for the Science...

Table 11. Difference in IEA of college students of different major types

\begin{tabular}{|c|c|c|c|c|}
\hline First-level index & Type of major & Mean & Standard deviation & F value \\
\hline \multirow{3}{*}{ Basic factors } & Liberal arts & 3.528 & 0.726 & \multirow{3}{*}{$19.241^{* * *}$} \\
\hline & Science and engineering & 4.271 & 0.779 & \\
\hline & Others & 3.987 & 0.864 & \\
\hline \multirow{3}{*}{ Environmental factors } & Liberal arts & 3.587 & 0.831 & \multirow{3}{*}{$17.428^{* * *}$} \\
\hline & Science and engineering & 4.242 & 0.774 & \\
\hline & Others & 4.042 & 0.824 & \\
\hline \multirow{3}{*}{ Input factors } & Liberal arts & 3.142 & 0.816 & \multirow{3}{*}{$15.953^{* * *}$} \\
\hline & Science and engineering & 4.333 & 0.774 & \\
\hline & Others & 4.046 & 0.943 & \\
\hline \multirow{3}{*}{ Personal factors } & Liberal arts & 3.459 & 0.875 & \multirow{3}{*}{$17.353^{* * *}$} \\
\hline & Science and engineering & 4.228 & 0.971 & \\
\hline & Others & 4.031 & 0.942 & \\
\hline \multirow{3}{*}{ Achievement factors } & Liberal arts & 3.178 & 0.881 & \multirow{3}{*}{$16.943^{* * *}$} \\
\hline & Science and engineering & 4.257 & 0.735 & \\
\hline & Others & 3.901 & 0.821 & \\
\hline \multirow{3}{*}{ Average level } & Liberal arts & 3.379 & 0.733 & \multirow{3}{*}{$17.379^{* * *}$} \\
\hline & Science and engineering & 4.266 & 0.790 & \\
\hline & Others & 4.001 & 0.874 & \\
\hline
\end{tabular}

Table 12 shows the post hoc test results of the difference in college students' IEA of different major types. According to the table, the IEA of college students majored in science and engineering is significantly better than those majored in liberal arts and other disciplines; the IEA of college students majored in law, management, and other disciplines is also better than liberal arts students. In terms of achievement factors, there is a large gap between liberal arts students and other students.

Table 13 shows the difference analysis of the IEA of college students of different genders. According to the table, the overall level is relatively balanced, but male students' scores in basic factors and personal factors are significantly higher than female students. The results of independent sample T-test show that, the overall IEA level of male and female students is consistent, indicating that the gender difference has little impact on the IEA of college students. 
Table 12. Post hoc test results of the difference in IEA of college students from different majors

\begin{tabular}{|c|c|c|c|c|}
\hline First-level index & Type of major & Mean & Standard deviation & Significance \\
\hline \multirow{3}{*}{ Basic factors } & Others & Liberal arts & 0.337 & 0.003 \\
\hline & \multirow{2}{*}{ Science and engineering } & Others & 0.297 & 0.002 \\
\hline & & Liberal arts & 0.576 & 0.005 \\
\hline \multirow{3}{*}{ Environmental factors } & Others & Liberal arts & 0.221 & 0.002 \\
\hline & \multirow{2}{*}{ Science and engineering } & Others & 0.297 & 0.003 \\
\hline & & Liberal arts & 0.659 & 0.008 \\
\hline \multirow{3}{*}{ Input factors } & Others & Liberal arts & 0.227 & 0.002 \\
\hline & \multirow{2}{*}{ Science and engineering } & Others & 0.275 & 0.003 \\
\hline & & Liberal arts & 0.753 & 0.010 \\
\hline \multirow{3}{*}{ Personal factors } & Others & Liberal arts & 0.348 & 0.004 \\
\hline & \multirow{2}{*}{ Science and engineering } & Others & 0.327 & 0.003 \\
\hline & & Liberal arts & 0.783 & 0.011 \\
\hline \multirow{3}{*}{ Achievement factors } & Others & Liberal arts & 0.278 & 0.003 \\
\hline & \multirow{2}{*}{ Science and engineering } & Others & 0.347 & 0.004 \\
\hline & & Liberal arts & 0.772 & 0.011 \\
\hline \multirow{3}{*}{ Average level } & Others & Liberal arts & 0.397 & 0.005 \\
\hline & \multirow{2}{*}{ Science and engineering } & Others & 0.212 & 0.002 \\
\hline & & Liberal arts & 0.828 & 0.014 \\
\hline
\end{tabular}

Table 13. Difference in IEA of college students of different genders

\begin{tabular}{|c|c|c|c|c|}
\hline First-level index & Gender & Mean & Standard deviation & T value \\
\hline \multirow{2}{*}{ Basic factors } & Male & 4.375 & 0.523 & \multirow{2}{*}{$3.014^{*}$} \\
\hline & Female & 4.221 & 0.621 & \\
\hline \multirow{2}{*}{ Environmental factors } & Male & 4.298 & 0.619 & \multirow{2}{*}{2.316} \\
\hline & Female & 4.241 & 0.622 & \\
\hline \multirow{2}{*}{ Input factors } & Male & 4.336 & 0.610 & \multirow{2}{*}{1.536} \\
\hline & Female & 4.331 & 0.626 & \\
\hline \multirow{2}{*}{ Personal factors } & Male & 4.428 & 0.593 & \multirow{2}{*}{$3.162^{*}$} \\
\hline & Female & 4.387 & 0.563 & \\
\hline \multirow{2}{*}{ Achievement factors } & Male & 4.361 & 0.618 & \multirow{2}{*}{1.168} \\
\hline & Female & 4.354 & 0.637 & \\
\hline \multirow{2}{*}{ Average level } & Male & 4.359 & 0.653 & \multirow{2}{*}{2.254} \\
\hline & Female & 4.306 & 0.627 & \\
\hline
\end{tabular}

\subsection{Construction of influencing factor model}

As a service industry, the service efficiency of the science and technology service industry will increase with the expansion of the industrial scale of the industry in the region, and the reduction in the fixed costs of corporate service is helpful to release and invest more funds and resources in innovative talent cultivation and introduction. Also, the expansion of the industrial scale can promote the cooperation among industries, universities and research institutes, which will further promote the transfor- 
mation of scientific and technological achievements of both schools and enterprises. The expansion of the industrial scale of the science and technology service industry has a positive effect on the improvement of college students' IEA, and they constitute a positive feedback relationship.

The scientific research investment in science and technology service industry is the economic support for knowledge and technological innovation. The innovation and research activities of innovative talents are the basis for the improvement of the innovation ability of the science and technology service industry in the region, and the patents and new products are the outcomes of such activities. Therefore, there is also a positive feedback relationship between the resource input of the science and technology service industry and the IEA of college students.

To promote the transfer and exchange of knowledge and technology between schools and enterprises, it's necessary to improve the informatization level of the region. For schools and enterprises in different regions and in different industries, the research and development cooperation platform between these schools and enterprises can reduce the $R \& D$ costs and time, improve the management efficiency of enterprises, and contribute to the improvement of the innovation ability of the science and technology service industry. Therefore, the informatization level of the science and technology service industry is positively correlated with the IEA of college students.

The science and technology service industry has the characteristics of high intelligence level and high added value; therefore, it requires to make full use of the "knowledge spillover effect" of services, equipment and other related factors generated in the process of school-enterprise clustering, and at the same time, it has to find suitable innovative talents with relatively low manpower costs, so as to improve the core competitiveness and advantages. The clustering effect can also reduce the fixed costs of corporate service and promote the introduction and cultivation of innovative talents in the science and technology service industry. Therefore, the degree of spatial agglomeration of the science and technology service industry is the last influencing factor, which also has a positive feedback relationship with the IEA of college students.

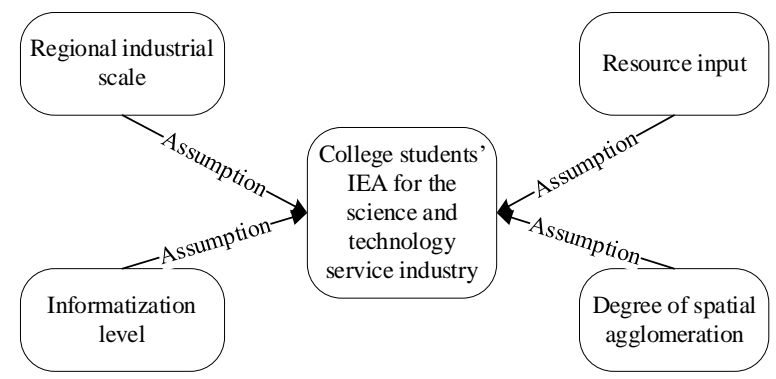

Fig. 5. Structure of the IEA influencing factor model

Based on the four influencing factors of the science and technology service industry, namely industrial scale, resource input, informatization level and the degree of spatial agglomeration, a college student IEA influencing factor model was construct- 
ed, as shown in Figure 5. The premise of the construction of this model is: the greater the positive impact of the four influencing factors, the stronger the IEA of college students for the science and technology service industry.

Based on Amos software, the path of the normalized influencing factor model was constructed as shown in Figure 6. The normalized regression coefficients are all less than 1 and greater than 0.9 or 0.08 , which has verified that the influencing factor model can fit well.

Table 14. Evaluation details and codes of the IEA influencing factor model

\begin{tabular}{|l|l|l|}
\hline First-level index & \multicolumn{1}{|c|}{ Details of second-level index (quantifiable) } & \multicolumn{1}{|c|}{ Code } \\
\hline \multirow{4}{*}{$\begin{array}{l}\text { Regional industrial } \\
\text { scale }\end{array}$} & Service efficiency of the science and technology service industry & $R I S_{1}$ \\
\cline { 2 - 3 } & Service object efficiency & $R I S_{2}$ \\
\cline { 2 - 3 } & Fixed cost of corporate service & $R I S_{3}$ \\
\cline { 2 - 3 } & External service utilization & $R I S_{4}$ \\
\cline { 2 - 3 } & Proportion of enterprises in the industry-university-research cooperation & $R I S_{5}$ \\
\hline \multirow{3}{*}{ Resource input } & Number of schools in school-enterprise R\&D cooperation & $S T R_{1}$ \\
\cline { 2 - 3 } & School-enterprise R\&D investment & $S T R_{2}$ \\
\cline { 2 - 3 } $\begin{array}{l}\text { Informatization } \\
\text { level }\end{array}$ & Education and training resource input of school-enterprise cooperation & $S T R_{3}$ \\
\hline \multirow{2}{*}{$\begin{array}{l}\text { Degree of spatial } \\
\text { agglomeration }\end{array}$} & Number of school-enterprise R\&D cooperation platforms & $I L_{1}$ \\
\cline { 2 - 3 } & Number of schools and enterprises implementing intensive management & $I L_{2}$ \\
\cline { 2 - 3 } & $\begin{array}{l}\text { Number of schools and enterprises in the region } \\
\text { enterprises }\end{array}$ & $S C_{3}$ \\
\hline
\end{tabular}

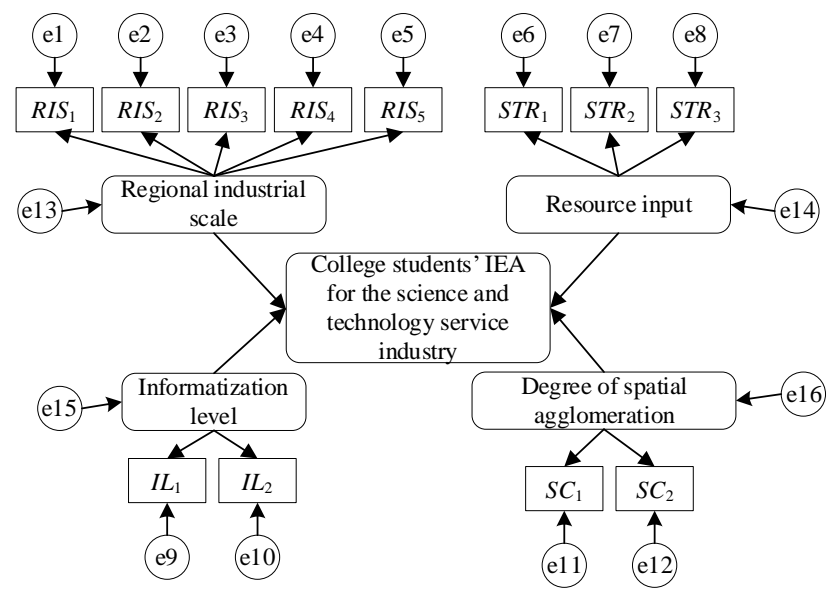

Fig. 6. Path of the normalized influencing factor model 
Table 15. Fitness of the influencing factor model

\begin{tabular}{|l|l|c|c|}
\hline \multicolumn{2}{|l|}{ Calibration index } & Critical value of fitness & Fitness \\
\hline \multirow{4}{*}{ Absolute fit index } & $\mathrm{X}^{2} / \mathrm{df}$ & $<5$ & 2.307 \\
\cline { 2 - 4 } & Root Mean Square Residual (RMSR) & $<0.08$ & 0.027 \\
\cline { 2 - 4 } & Goodness of fix index (GFI) & $>0.9$ & 0.931 \\
\hline \multirow{5}{*}{ Comparative fit index } & Normed fit index (NFI) & $>0.9$ & 0.954 \\
\cline { 2 - 4 } & Incremental fit index (IFI) & $>0.9$ & 0.958 \\
\cline { 2 - 4 } & Tucker-Lewis index (TLI) & $>0.9$ & 0.924 \\
\cline { 2 - 4 } & Comparative fit index (CFI) & $>0.9$ & 0.977 \\
\hline \multirow{2}{*}{ Parsimony fit index } & Parsimony goodness of fit index (PGFI) & $>0.9$ & 0.979 \\
\cline { 2 - 4 } & Parsimony goodness of fit index (PGFI) & $>0.9$ & 0.916 \\
\hline
\end{tabular}

Table 15 gives the calibration index values of the fitness of the influencing factor model, and all values are within an ideal normalization range, which further verified that the model fits the evaluation index data well. Table 16 gives the corresponding reliability and validity test results. The reliability and validity of each quantifiable second-level index are good.

Table 16. Reliability and validity test results of the influencing factor model

\begin{tabular}{|c|c|c|c|}
\hline First-level index & Code of second-level index & Load of normalization factor & Calibration coefficient \\
\hline \multirow{5}{*}{$\begin{array}{l}\text { Regional industrial } \\
\text { scale }\end{array}$} & $R I S_{1}$ & \begin{tabular}{|c|}
0.821 \\
\end{tabular} & \multirow{5}{*}{0.889} \\
\hline & $R I S_{2}$ & 0.833 & \\
\hline & $R I S_{3}$ & 0.896 & \\
\hline & $R I S_{4}$ & 0.921 & \\
\hline & $R I S_{5}$ & 0.907 & \\
\hline \multirow{3}{*}{ Resource input } & $S T R_{1}$ & 0.951 & \multirow{3}{*}{0.921} \\
\hline & $\mathrm{STR}_{2}$ & 0.867 & \\
\hline & $\mathrm{STR}_{3}$ & 0.937 & \\
\hline \multirow{2}{*}{$\begin{array}{l}\text { Informatization } \\
\text { level }\end{array}$} & $I L_{1}$ & 0.911 & \multirow{2}{*}{0.919} \\
\hline & $I L_{2}$ & 0.927 & \\
\hline \multirow{2}{*}{$\begin{array}{l}\text { Degree of spatial } \\
\text { agglomeration }\end{array}$} & $S C_{3}$ & 0.857 & \multirow{2}{*}{0.883} \\
\hline & $S C_{2}$ & 0.905 & \\
\hline
\end{tabular}

Table 17. Path effect analysis of the influencing factor model

\begin{tabular}{|l|c|c|l|}
\hline \multicolumn{1}{|c|}{ Correlation } & Path coefficient & Significance & \multicolumn{1}{c|}{ Test result } \\
\hline Regional industrial scale_> IEA of college students & 0.685 & $*$ & Not support \\
\hline Resource input_-> IEA of college students & 0.843 & $* * *$ & Support \\
\hline Informatization level---> IEA of college students & 0.798 & $* * *$ & Support \\
\hline $\begin{array}{l}\text { Degree of spatial agglomeration---> IEA of college } \\
\text { students }\end{array}$ & 0.698 & $*$ & Not support \\
\hline
\end{tabular}

The path effect analysis results of the influencing factor model are shown in Table 17. When the path coefficient from the resource input and informatization level to the IEA of college students is respectively 0.843 and 0.798 , it obeys the assumption, indicating that the resource input and informatization level of the science and technology service industry in the region has a significant impact on the IEA of college stu- 
dents; the regional industrial scale and degree of spatial agglomeration have an impact on it, but the influence has not reached a significant level.

\section{Conclusion}

This paper innovatively constructed an evaluation model of college students' IEA for the science and technology service industry. First, the paper constructed a corresponding evaluation index system and conducted factor analysis on the quantifiable index data, then, based on the maximum likelihood method, the corresponding structural equation model was subject to regression estimation. Second, from multiple aspects such as the level of the college, the major of the student, and the gender of the student, this paper comprehensively analyzed college students' IEA and performed difference analysis and post hoc test. At last, this paper constructed an influencing factor path analysis model and analyzed the relationship between regional industrial scale, resource input, informatization level, and degree of spatial agglomeration of the science and technology service industry, and college students' IEA; it also gave the fitness of the model, the reliability and validity test results, and the path effect analysis results of the influencing factor model.

\section{References}

[1] Shafigullina, A.V., Akhmetshin, R.M., Martynova, O.V., Vorontsova, L.V., Sergienko, E.S. (2020). Analysis of entrepreneurial activity and digital technologies in business. In Digital Transformation of the Economy: Challenges, Trends and New Opportunities, 908: 183-188. https://doi.org/10.1007/978-3-030-11367-4_17

[2] Alhashimi, M., Reyad, S., Hamdan, A., Badawi, S., Al-Sartawi, A., Razzaque, A. (2019). Entrepreneurial Competencies and Firm Performance: Evidence from Bahrain. In International Conference on Innovation and Entrepreneurship, 1: 49-58. https://doi.org/10. 34190/ECIE.19.014

[3] Kummitha, R.K.R. (2018). Entrepreneurial urbanism and technological panacea: Why Smart City planning needs to go beyond corporate visioning? Technological Forecasting and Social Change, 137: 330-339. https://doi.org/10.1016/j.techfore.2018.07.010

[4] Mehmood, M.S., Jian, Z., Waheed, A. (2019). The influence of entrepreneurial leadership on organisational innovation: mediating role of innovation climate. International Journal of Information Systems and Change Management, 11(1): 70-89. https://doi.org/10.1504/IJI SCM.2019.101650

[5] Wang, G., Liu, X., Xing, R. (2019). Impact of Prior Experience of Entrepreneur on Entrepreneurial Orientation of New Ventures. In European Conference on Innovation and Entrepreneurship, 2: 1093-1101. https://doi.org/10.34190/ECIE.19.139

[6] Guerrero, M., Urbano, D. (2019). Effectiveness of technology transfer policies and legislation in fostering entrepreneurial innovations across continents: an overview. The Journal of Technology Transfer, 44(5): 1347-1366. https://doi.org/10.1007/s10961-019$\underline{09736-\mathrm{X}}$

[7] Greiner, C., Peisl, T. (2019). Design thinking in entrepreneurship textbooks Entrepreneurial education issues between requirements and reality. IMSCI 2019 - 13th International Multi-Conference on Society, Cybernetics and Informatics, Proceedings, 2: 74-79. 
[8] Saha, N., Sáha, P. (2020). Entrepreneurial Universities Inclusive Perspective: Does it Trigger Social Innovation Process and Entrepreneurship? In European Conference on Innovation and Entrepreneurship, 2020: 568-577. https://doi.org/10.34190/EIE.20.082

[9] Song, C., Park, K.M., Kim, Y. (2020). Socio-cultural factors explaining technology-based entrepreneurial activity: Direct and indirect role of social security. Technology in Society, 101246. https://doi.org/10.1016/j.techsoc.2020.101246

[10] Qi, Y., Wang, J. (2020). A Talent Cultivation Model for Improving the Innovation Ability of College Students in Scientific Research, International Journal of Emerging Technologies in Learning, 15(18): 151-164.

[11] Sadli, N., Mohamad, M.M., Mohamad, M., Ahmad, A. (2019). Teaching Entrepreneurship: Impartation of Entrepreneurial Characteristics in Teaching Strategies. In 2019 IEEE 11th International Conference on Engineering Education (ICEED), 228-233. https://doi.org/ 10.1109/ICEED47294.2019.8994910

[12] Yu, S., Johnson, S., Lai, C., Cricelli, A., Fleming, L. (2017). Crowdfunding and regional entrepreneurial investment: an application of the CrowdBerkeley database. Research Policy, 46(10): 1723-1737. https://doi.org/10.1016/j.respol.2017.07.008

[13] Ngongoni, C.N., Grobbelaar, S.S., Schutte, C.S.L. (2017). The role of open innovation intermediaries in entrepreneurial ecosystems design. South African Journal of Industrial Engineering, 28(3): 56-65. http://dx.doi.org/10.7166/28-3-1839 .

[14] Teixeira, S.J., Casteleiro, C.M.L., Rodrigues, R.G., Guerra, M.D. (2018). Entrepreneurial intentions and entrepreneurship in European countries. International Journal of Innovation Science, 10(1): 22-42. https://doi.org/10.1108/IJIS-07-2017-0062

[15] Allen, T.R. (2018). Entrepreneurial Nuclear and the Associated Challenges for Materials Development. Transactions, 118(1): 1353-1353.

[16] Boutell, M.R., Fisher, D.S. (2017). Entrepreneurial minded learning in app development courses. In 2017 IEEE Frontiers in Education Conference (FIE), 1-8. https://doi.org/10. 1109/FIE.2017.8190436

[17] Inouye, T.M. (2016). Militarization as a socio-political context for entrepreneurial innovation. In 2016 49th Hawaii International Conference on System Sciences (HICSS), 4093-4102. https://doi.org/10.1109/HICSS.2016.508

[18] Blanco-Mesa, F., Merigó, J.M., Kacprzyk, J. (2016). Bonferroni means with distance measures and the adequacy coefficient in entrepreneurial group theory. Knowledge-Based Systems, 111: 217-227. https://doi.org/10.1016/j.knosys.2016.08.016

[19] Efendi, A., Aziz, F., Saepudin, D., Hendajany, N., Setiawan, H., Altin, F.A.H. (2019). Build the Technopreneurship Learning and Entrepreneurial Ecosystem to Create the Entrepreneurial Spirit at Universitas Sangga Buana. In 2019 IEEE 13th International Conference on Telecommunication Systems, Services, and Applications (TSSA), 240-242. https://doi.org/10.1109/TSSA48701.2019.8985462

[20] Perez-Encinas, A., Fernandez-de-Pinedo, N., Feijoo, C.G., Rickmann, J. (2018). How to Build Entrepreneurial Knowledge for University Students? Approaches from an European Perspective. In International Conference on Innovation and Entrepreneurship, 580-586.

[21] Audretsch, D.B., Belitski, M. (2017). Entrepreneurial ecosystems in cities: establishing the framework conditions. The Journal of Technology Transfer, 42(5): 1030-1051. https://doi. org/10.1007/s10961-016-9473-8

[22] Malebana, M.J., Zindiye, S. (2017). Relationship between entrepreneurship education, prior entrepreneurial exposure, entrepreneurial self-efficacy and entrepreneurial intention. In European Conference on Innovation and Entrepreneurship, 2017: 392-399.

[23] Wen, F., Tang, Y. (2016). The nonlinear Polya process of entrepreneurial agglomeration. Journal of Interdisciplinary Mathematics, 19(5-6): 1095-1107. https://doi.org/10.1080/09 $\underline{720502.2016 .1276699}$ 
[24] Gianiodis, P.T., Meek, W.R. (2020). Entrepreneurial education for the entrepreneurial university: a stakeholder perspective. The Journal of Technology Transfer, 45: 1167-1195. https://doi.org/10.1007/s10961-019-09742-Z

[25] Gumbi, N., van der Westhuizen, T. (2020). Youth Entrepreneurial Self-Efficacy Towards Technology for Online Business Development. In ECIE 2020 16th European Conference on Innovation and Entrepreneurship, 270-279. https://doi.org/10.34190/EIE.20.225

\section{Authors}

Yanming Qi was born in 1980. She graduated from Hebei Normal University with a bachelor's degree in 2003 and Hebei University with a master's degree in 2010. Since 2003, she had been working in School of Humanity and Law, Hebei University of Engineering, engaged in Chinese language and literature, ideological and political education and scientific research for college students.

Tong Liang was born in 2000. She is an undergraduate student at Hebei University and enrolled in 2018. In particular, she is very interested in mathematical modeling and empirical research.

Yongzhi Chang was born in 1982. She graduated from Inner Mongolia University with a bachelor's degree in 2004, Northeast Normal University with a master's degree in 2009 and Northeast Normal University with a doctor 's degree in 2013. She engaged in postdoctoral research in Institute of Geographical Sciences and resources, Chinese Academy of Sciences from 2014 to 2018. Since 2019, she had been working in School of Economics and Management, North China Institute of Aerospace Engineering, engaged in teaching and scientific research in regional economic development.

Article submitted 2021-01-13. Resubmitted 2021-02-11. Final acceptance 2021-02-13. Final version published as submitted by the authors. 